\title{
Aplikasi Pengelolaan Rumah Berkas Wajib Pajak di Kantor Pelayanan Pajak Pratama
}

\section{Application for Management Files House Taxpayers in Pratama Tax Service Office}

\author{
Fitri Nuraeni ${ }^{1}$, Puspa Rahayu ${ }^{2}$ \\ ${ }^{1,2}$ STMIK Tasikmalaya; Jalan RE Martadinata 272A Tasikmalaya, (0265)310830 \\ STMIK Tasikmalaya, Tasikmalaya. \\ *11nenk.ufit@gmail.com, ${ }^{2}$ puspa-rahayu@stmik-tasikmalaya.ac.id
}

\begin{abstract}
File management debt collection letter of the taxpayer in the Tax Office Primary use the term home taxpayer files. Where in the maintenance of the file is still using the process of recording data on the ledger and the physical storage of records in a file cabinet. The amount of storage shelves and files are kept very much lead in the file search process takes a long time. Supervision existence archive documents is very difficult to do if you have to check the house when the order to each file.By utilizing databases and application managers, can be designed application manager of the file that works to help the storage of data files and check the existence of a letter to the home archive file. This application design using the Waterfall method using a structured approach flowmap, context diagrams, data flow diagrams and entity relationship diagrams as design data base.Management of application design house taxpayer files, intended in order to overcome the problems that occur in the Collection Section Tax Office Primary, so that the process of debt collection file management taxpayer for faster and easier.
\end{abstract}

Keywords-Home Files, File Collection, Tax Debt, The Taxpayer

\begin{abstract}
Abstrak
Pengelolaan berkas surat penagihan utang pajak dari wajib pajak di Kantor Pelayanan Pajak Pratama menggunakan istilah rumah berkas wajib pajak. Dimana dalam pemeliharaan berkasnya masih menggunakan proses pencatatan data pada buku besar dan penyimpanan fisik arsip pada lemari arsip. Banyaknya rak penyimpanan dan berkas yang disimpan mengakibatkan dalam proses pencarian berkas memakan waktu yang cukup lama. Pengawasan keberadaan dokumen arsippun sangat sulit dilakukan jika harus mengecek rumah berkas setiap saat. Dengan memanfaatkan basis data dan aplikasi pengelolanya, dirancang aplikasi pengelola rumah berkas yang bekerja membantu penyimpanan data berkas dan mengecek keberadaan suatu arsip surat pada rumah berkas. Aplikasi ini dirancang menggunakan metode Waterfall dengan pendekatan terstruktur menggunakan flowmap, diagram konteks, diagram alir data dan entity relationship diagram sebagai perancangan basis datanya. Dengan adanya aplikasi pengelolan rumah berkas wajib pajak ini dapat mengatasi masalah yang terjadi di Seks Penagihan Kantor Pelayanan Pajak Pratama, sehingga proses pengelolaan berkas penagihan utang pajak wajib pajak lebih cepat dan mudah.
\end{abstract}

Kata kunci-Rumah Berkas, Berkas Penagihan, Utang Pajak, Wajib Pajak

\section{PENDAHULUAN}

Kantor Pelayanan Pajak Pratama dibentuk dengan "meleburkan" tiga jenis kantor pelayanan yang ada selama ini yakni, KPP, KPPBB, dan Karikpa. Meskipun terdapat penggabungan tugas pokok dan fungsi yang melekat pada kantor-kantor tersebut tetap ada, melalui struktur baru pada KPP Pratama yang berbasis fungsi. Fungsi-fungsi yang dimaksud antara lain meliputi fungsi Pelayanan, fungsi Pengawasan dan Konsultasi yang 
memperkenalkan Account Representatif (AR), fungsi Penagihan, fungsi Pemeriksaan, fungsi Ekstensifikasi, dan terakhir fungsi Pengolahan Data dan Informasi.

Fungsi penagihan yang dilakukan Seksi Penagihan dengan mengelola arsip surat dan berkas yang berkaitan dengan penagihan utang pajakwajib pajak, seperti :Arsip Surat Tagihan Pajak (STP) / Surat Ketetapan Pajak (SKP), Arsip Surat Teguran, Arsip Surat Paksa, Arsip Surat Perintah Melakukan Penyitaan (SPMP), Arsip Surat Blokir, Arsip Surat Lelang, Surat Keputusan Penambahan Piutang, Surat Keputusan Pengurangan Piutang, Surat Setoran Pajak (SSP) dan Pemindahbukuan (PBK)[1].

Surat-surat tersebut saling berkaitan satu sama lainnya, dimulai dari Surat Ketetapan Pajak (SKP) yang diterbitkan ketika wajib pajak tidak melakukan kewajiban membayar pajak. SKP merupakan alat untuk menagih pajak dan pada umumnya wajib pajak segera melunasi hutang pajaknya, jika hutang pajak belum dibayarkan maka dirjen pajak dapat melakukant indakan penagihan pajak sesuai dengan jumlah pajak terutang berdasarkan Surat Tagihan Pajak (STP)[2]. Kemudian secara bertahap tindakan penagihan dilakukan dengan menerbitkan suratsurat lainnya. Mengingat setiap berkas yang diterbitkan sangat penting dan berkaitan maka semua jenis berkas penagihan harus digabungkan dalam sebuah wadah per NPWP/per wajib pajak, yang dinamakan Rumah Berkas. Jadi satu NPWP, memiliki satu rumah berkas, dan didalam satu Rumah Berkas itu terdiri dari beberapa jenis berkas (termasuk ke-9 jenis surat diatas)/ terdiri dari berkas-berkas yang berkaitan dengan NPWP/Wajib Pajak tersebut.

Sistem pemberkasan adalah susunan yang teratur dalam bentuk berkas yang ditata sedemikian rupa sehingga masalah yang disimpan dapat terlihat secara jelas dan memudahkan dalam penemuan kembali, meliputi : (a) Seri adalah arsip/berkas yang disusun berdasarkan kesamaan jenis; (b) Rubrik adalah arsip/ berkas yang disusun berdasarkan kesamaan masalah; (c) Dosir adalah arsip/berkas yang disusun atas dasar kesamaan urusan atau kegiatan[3].

Namun jika pengelolaan arsip pada rumah berkas wajib pajak yang masih menggunakan proses pencatatan data pada buku besar dan penyimpanan fisik arsip pada lemari arsip. Banyaknya rak penyimpanan dan berkas yang disimpan sangat banyak mengakibatkan dalam proses pencarian berkas memakan waktu yang cukup lama. Pengawasan keberadaan dokumen arsip sangat sulit dilakukan jika harus mengecek rumah berkas setiap saat, serta semakin banyaknya berkas yang diarsipkan mengakibatkan sulitnya pengidentifikasian di kemudian hari.

Adanya basis data dapat menyelesaikan masalah kesulitan akses data dan integrasi data[4]. Namun basis datapun masih memerlukan aplikasi untuk mengelolanya. Program aplikasi (sering kali hanya disebut aplikasi saja) adalah program yang dibuat oleh pemakai yang ditujukan untukmelakukan suatu tugas khusus[5]. Aplikasi yang dibuat adalah sebagai media pengolahan data yaitu media yang digunakan untuk mengambarkan perubahan bentuk data menjadi informasi yang memiliki kegunaan[6].

Penelitian serupa mengenai pengembangan aplikasi untuk mengelola arsip surat banyak dilakukan khususnya surat masuk dan surat keluar pada suatu organisasi atau perusahaan. Salah satu keuntungan adanya sistem informasi pengarsipan surat masuk dan surat keluar ini dapat mempercepat proses pencarian karena data-data tersimpan dengan aman dan struktur[7]. Selain itu juga, dengan adanya rekapan data surat masuk dan surat keluar dapat membantu mengontrol keberadaan bukti fisik atau dalam rekapan bentuk digitilalisasi bukti fisik[8]. Merujuk pada pengembangan sistem informasi pengelolaan surat masuk dan surat keluar yang banyak dibuat maka untuk membantu mengelola arsip surat tagihan pajak dapat dibangun juga aplikasinya. Dengan keadaan lapangan mengenai rumah berkas wajib pajak yang banyak serta arsip surat tagihan yang penting untuk disimpan, maka aplikasi berbasis database sangat dibutuhkan untuk membantu proses pengelolaannya.

Oleh karena itu, dengan adanya aplikasi pengelola rumah berkas wajib pajak ini, dapat membantu dalam merekap data arsip surat tagihan wajib pajak dan rumah berkasnya secara terstruktur, sehingga pencarian arsip bisa lebih cepat. Selain itu juga dapat membantu mengontrol arsip surat tagihan yang ada bentuk fisikny dan yang tidak bentuk fisiknya. 


\section{METODE PENELITIAN}

Dalam perancangan aplikasi ini digunakan metodeWaterfall. Metode Waterfall diawali dengan analisis data, perancangan sistem, pembangunan aplikasi menggunakan Visual Basic 6.0[9]. Proses pertama yang dilakukan adalah pengumpulan data dengan melakukan wawancara dengan Seksi Penagihan di Kantor Pelayanan Pajak Pratama Kabupaten Ciamis. Dari hasil wawancara didapatkan data yang akan digunakan untuk setiap proses perancangan aplikasi.

\subsection{Analisis Sistem}

Menganalisa dari sistem yang berjalan dengan analisis kelemahan sistem yang ada,serta mengumpulkan kebutuhan-kebutuhan sistem yang akan dibangun[10]. Berdasarkan hasil wawancara diindentifikasi permasalahan yang ada dalam proses pengelolaan rumah berkas ini adalah : 1) proses penyimpanan surat/ berkas masih berupa dokumen arsip yang berbentuk fisik dan semua surat/ berkas yang dimiliki tiap wajib pajak disimpan dalam satu wadah yang disebut rumah berkas; 2) data surat/ berkas masih diinput dan disimpan pada sebuah file worksheet, yang makin hari makin bertambah dan menyulitkan untuk pencarian. 3) Rumah Berkas yang sudah diinput kemudian disimpan/dijajarkan di sebuah Rak terbuka sesuai dengan nomor urut; dan 4) proses pencarian arsip yang membutukan waktu lama.

Selanjutnya dari indentifikasi masalah tersebut dilakukanlah analisis kelemahan sistem yang berjalan, sehingga ditemukan beberapa kelemahan yaitu : (1) penyimpanan data masih menggunakan arsip, sehingga menyulitkan dalam pencarian di karenakan arsip yang berupa dokumen sering terjadi kehilangan atau rusak, pengurutan, penghitungan data dan tidak adanya penyimpanan data yang tersusun; (2) sulitnya ketika menentukan ada/tidaknya berkas fisik dalam sebuah rumah berkas, karena harus dibuka satu per satu untuk memastikannya, sedangkan Rumah Berkas itu terdiri dari +/- 7.000 buah dan kemungkinan akan terus bertambah dikarenakan WP yang daftar dan menunggak terus bertambah; (3)Terlambatnya ketika mendapatkan informasi mengenai jenis-jenis berkas yang berada di dalam rumah berkas per Wajib Pajak.

Oleh karena itu pada aplikasi yang akan dirancang, dibutuhkan adanya kemampuan untuk: (1) menyimpan data wajib pajak dan rincian berkas arsip surat apa saja yang dimiliki oleh wajib pajak berserta posisipadalemari arsip; (2) dapat mengetahui jika ada surat tagihan tahapan sebelumnya yang belum tersimpan jika akan menyimpan data surat tagihan baru; (3) dapat menyajikan informasi tagihan terakhir yang dikenakan pada wajib pajak.

Namun untuk memokuskan penyelesaian masalah pengelolaan rumah berkas ini maka dibatasi hanya meliputi : 1) aplikasi yang dibangun hanya dapat dijalankan pada bagian Seksi Penagihan, khusus Bagian Pelaksana yaitu sub bagian khusus pengelola rumah berkas; 2) sistem yang dibangun meliputi perincian arsip berkas yang dimiliki setiap wajib pajak, back-up arsip, pencarian arsip, dan pembuatan laporan perincian arsip surat ketetapan utang pajak dan surat penagihan utang pajak tersebut; 3 ) sistem yang dibangun tidak membahas tentang pemusnahan arsip; dan 4) sistem yang dibangun hanya membahas jenis pajak PPh dan PPN.

\subsection{Desain sistem}

Perancangan ini menggunakan tool berupa flowmap usulan, diagram konteks, diagram arus data, rancangan database, dan rancangan antar muka.

Prosedur berikut ini menggambarkan jalannya pekerjaan :

1. Bagian Penagihan membuat berkas admisitasi Wajib Pajak seperti :
a. Arsip Surat Tagihan Pajak (STP) / Surat Ketetapan Pajak (SKP),
b. Arsip Surat Teguran,
c. Arsip Surat Paksa,
d. Arsip Surat Perintah Melakukan Penyitaan (SPMP),
e. Arsip Surat Blokir, Arsip Surat Lelang,
f. Surat Keputusan Penambahan Piutang,
g. Surat Keputusan Pengurangan Piutang, 
h. Surat Setoran Pajak (SSP)

i. Pemindahbukuan (PBK).

2. Berkas admisitasi tersebut dibuat rangkap 2, satu diserahkan pada Wajib Pajak dan satu lagi diserahkan pada Bagian Pelaksana Rumah Berkas untuk diarsipkan.

3. Bagian pelaksana memasukan semua STP/SKP per NPWP ke dalam Rumah Berkas, dan menuliskan : NPWP, Nama Wajib Pajak dan Alamat di bagian depan/sampul Rumah Berkas.

4. Menginput data yang tertera di sampul Rumah Berkas (NPWP, Nama Wajib Pajak dan Alamat) pada database melalui aplikasi yang akan dibangun.

5. Rumah Berkas yang sudah diinput kemudian disimpan di sebuah Rak terbuka sesuai dengan nomor urut.

6. Arsip surat Teguran, Surat Paksa, SPMP, Surat Blokir, Surat Lelang, Surat Keputusan Penambahan Piutang, Surat Keputusan Pengurangan Pitang, SSP dan PBK pun menyusul dimasukan ke dalam Rumah berkas sesuai dengan NPWPnya. Sebelumnya diinputkan pada database melalui aplikasi sehingga data arsip surat tersimpan disana untuk memudahkan pencarian dan pengawasan pemeliharaan berkas.

7. Saat Bagian Penagihan atau unit lainnya membutuhkan informasi administrasi Wajib Pajak, Bagian Pelaksana dapat mengakses informasi melalui aplikasi.

8. Jika berkas ditemukan maka dapat diserhakan pada unit yang membutuhkan. Jika tidak, maka memberikan informasi berkas tidak ada. Selanjutnya dicetak laporan untuk setiap berkas surat tagihan pajak yang fisik arsipnya tidak ada di rumah berkas.

Prosedur diatas digambarkan pada Flow Map yang merupakan aliran data berbentuk dokumen atau formulir didalam suatu sistem informasi yang merupakan suatu aktivitas yang saling terkait dalam hubungannya dengan kebutuhan data dan informasi[11]. Untuk proses pengelolaan arsip rumah berkas ini digambarkan pada flowmap gambar 1 .

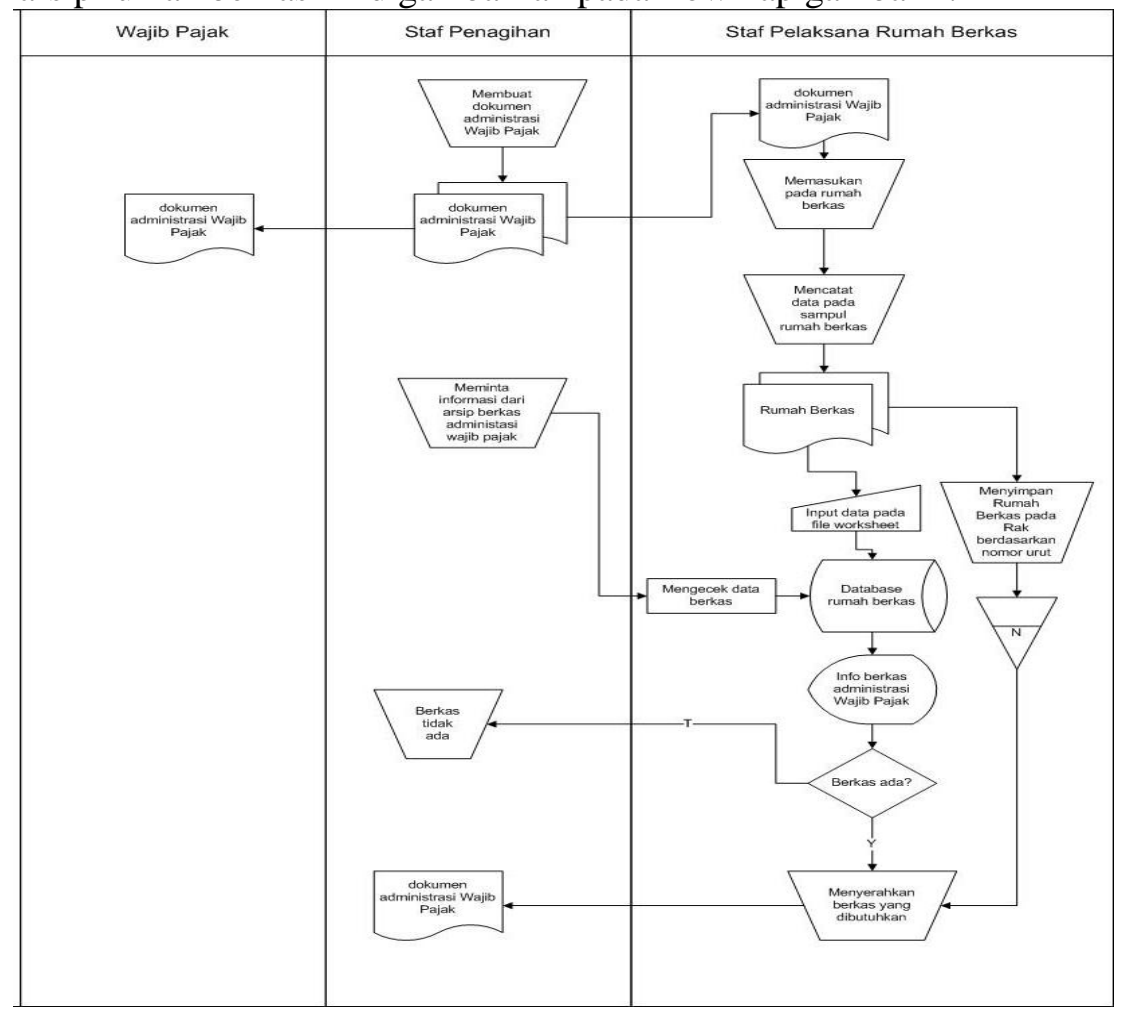

Gambar 1. Flowmap sistem pengelolaan arsip surat tagihan pada rumah berkas. 
Pada sistem pengelolaan surat tagihan pajak terdapat empat entitas yaitu 1)Wajib Pajak yang merupakan objek yang memiliki data wajib pajak, data utang pajak dan data surat tagihan utang pajak; 2) Bagian Penagihan yang bertugas membuatkan surat tagihan utang pajak dan menginputkan data tersebut pada aplikasi; 3) Bagian Pelaksana yang bertugas memelihara rumah berkas dan mengupdate data pada database secara berkala sehingga aplikasi pengelola rumah berkas ini dapat menghasilkan informasi yang akurat 4) Unit lainnya yang ada di Kantor Pelayanan Pajak Pratama yang membutuhkan informasi mengenai arsip surat tagihan utang pajak.

Untuk menggambarkan data dan informasi yang masuk dan dihasilkan oleh aplikasi ini menggunakan Diagram Konteks seperti pada gambar 2.

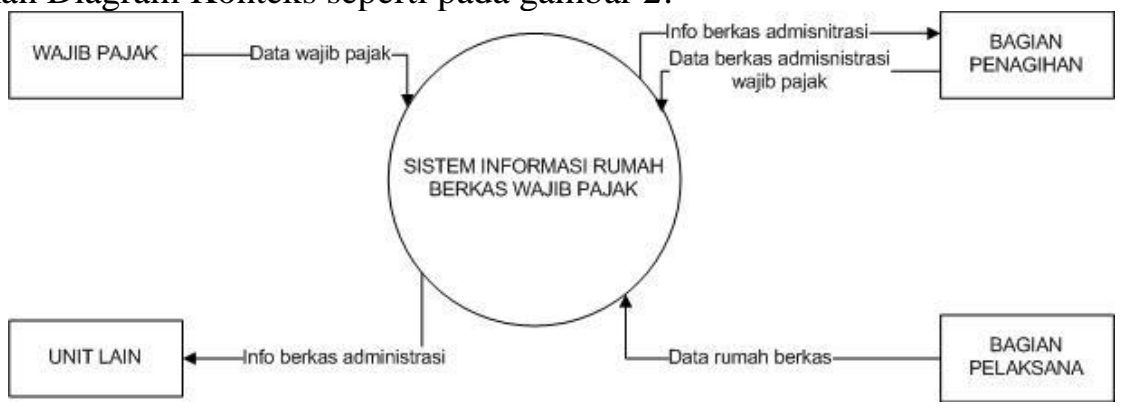

Gambar 2. Diagram konteks sistem pengelolaan arsip surat tagihan pada rumah berkas

Proses yang dilakukan oleh aplikasi yang dirancang untuk pengelolaan rumah berkas digunakan Diagram Alir Data (DAD) dri level 0 (gambar3) dan level 1 (gambar 4). Pada gambar 3 memuat aliran data dan proses utama yang akan terjadi pada aplikasi yang dirancang. Pertama adalah proses pengolahan data wajib pajak yang merupakan sumber data master. Selanjutnya setiap wajib pajak yang memiliki ketetapan utang pajak akan menerima surat tagihan dan arsip surat tersebut disimpan pada rumah berkas. Data surat-surat tersebut akan masuk melalui proses pengolahan data rumah berkas. Dengan adanya data surat-surat tagihan utang pajak, Bagian Pelaksana dapat memberikan pelayanan informasi dengan lebih cepat dan mudah karena aplikasi dilengkapi fasilitas pencarian data dan pencetakan laporan.

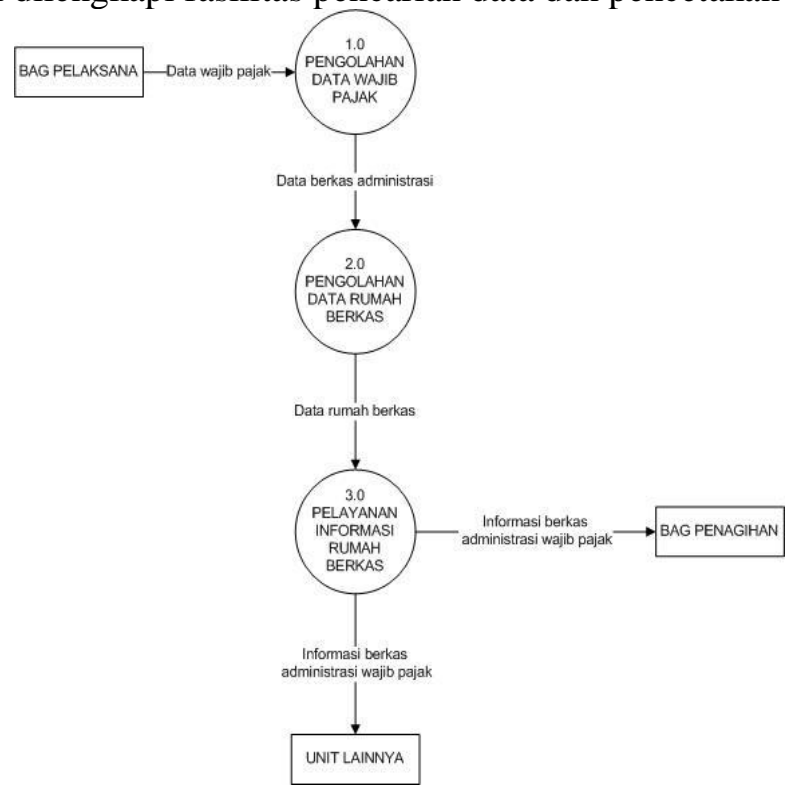

Gambar 3. Diagram alir data pengelolaan arsip surat tagihan pada rumah berkas level 0 


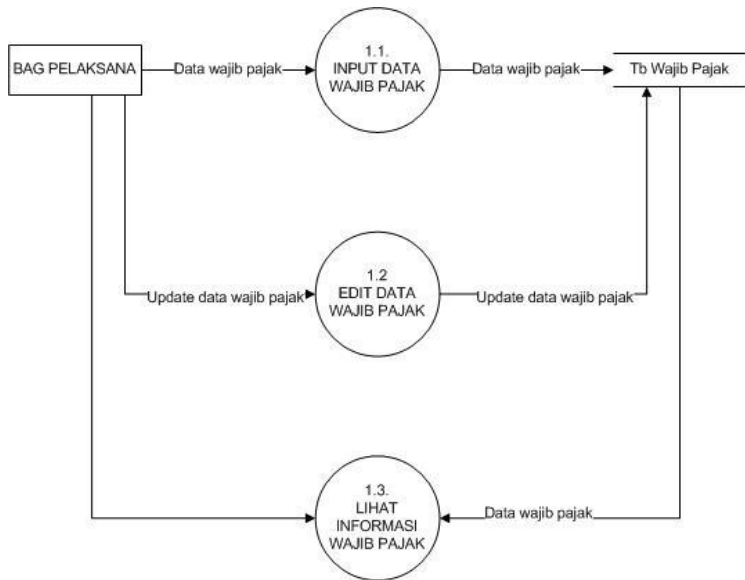

(a)

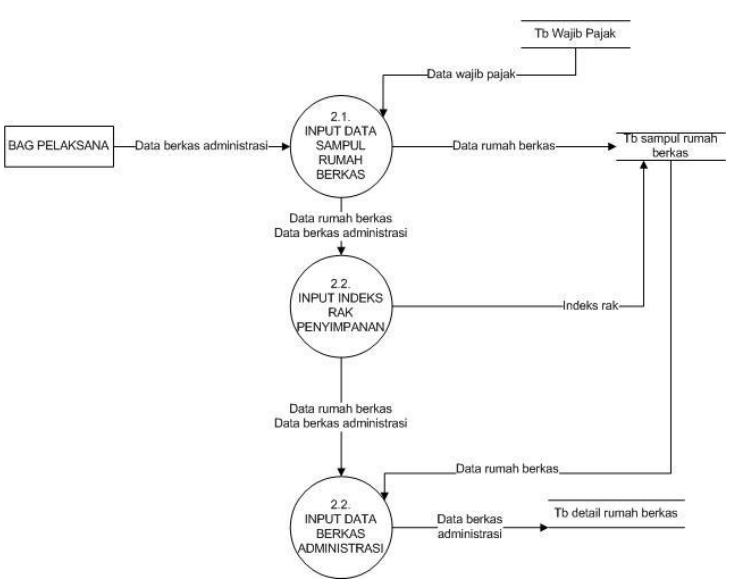

(b)

Gambar 4. Diagram alir data pengelolaan arsip surat tagihan pada rumah berkas level 1

Khusus untuk data wajib pajak alur pengolahan data sesuai dengan gambar 4 (a) dimana data yang masuk disimpan pada table wajib pajak dan Bagian Pelaksana dapat melakukan update data jika diperlukan serta melihat informasi wajib pajak melalui fasilitas pencarian data wajib pajak. Sedangkan untuk data arsip surat tagihan utang pajak secara rinci digambarkan pada gambar 4 (b). Proses pengelolaan data arsip rumah berkas ini terdiri dari 3 proses yaitu 1) input data sampul rumah berkas yang mengelola data rumah berkas sesuai wajib pajak; 2) input indeks penyimpanan pada lemari arsip untuk memudahkan pencarian fisik dari rumah berkas; 3 ) input berkas arsip yang ada pada rumah berkas untuk mempermudah pemeliharaan dan pengawasan berkas fisik surat tagihan pajak.

Sedangkan untuk perancangan basis datanya dihasilkan 4 tabel yaitu table rumah berkas, table ketetapan tunggakan, table wajib pajak dan table tindakan penagihan. Relasi antar table tersebut dapat dilihat pada gambar 5.

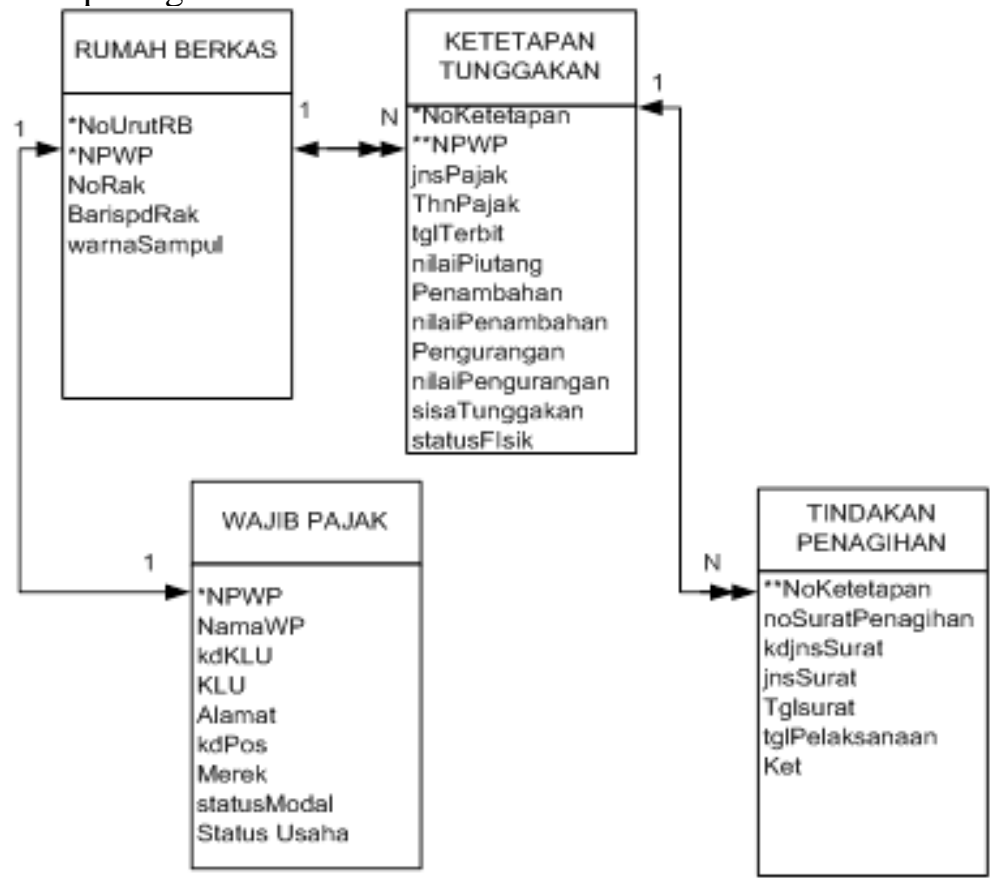

Gambar 5. Relasi antar table untuk aplikasi pengelolaan arsip surat tagihan pada rumah berkas 2.3. Pembuatan Program 
Selanjutnya mengubah desain menjadi bentuk yang dimengerti oleh komputer, maka dilakukan penulisan jika desainnya detail maka penulisan program dapat dicapai. Pertama-tama dibuat basis data sesuai dengan rancangan pada gambar 5 menggunakan Ms. Access 2007.

Setelah itu dibuatkan aplikasi pengelola untuk database tersebut dengan menggunakan Miscrosoft Visual Basic 6.0. Aplikasi yang dibuat menerapkan proses pengolahan data sesuai dengan bagan alir data pada gambar 3 dan gambar 4 .

Menu utama dari aplikasi yang dibangun, terdiri dari 3 menu, yaitu: File untuk pengelolaan pengguna aplikasi, Operasional berisi menu-menu pengelolaan NPWP dan surat tagihan pajak serta yang terakhir adalah menu Laporan untuk kebutuhan mencetak laporanlaporan terkait informasi arsip surat tagihan pajak pada rumah berkas. Detail rancangan menu sepertipadagambar 6 .

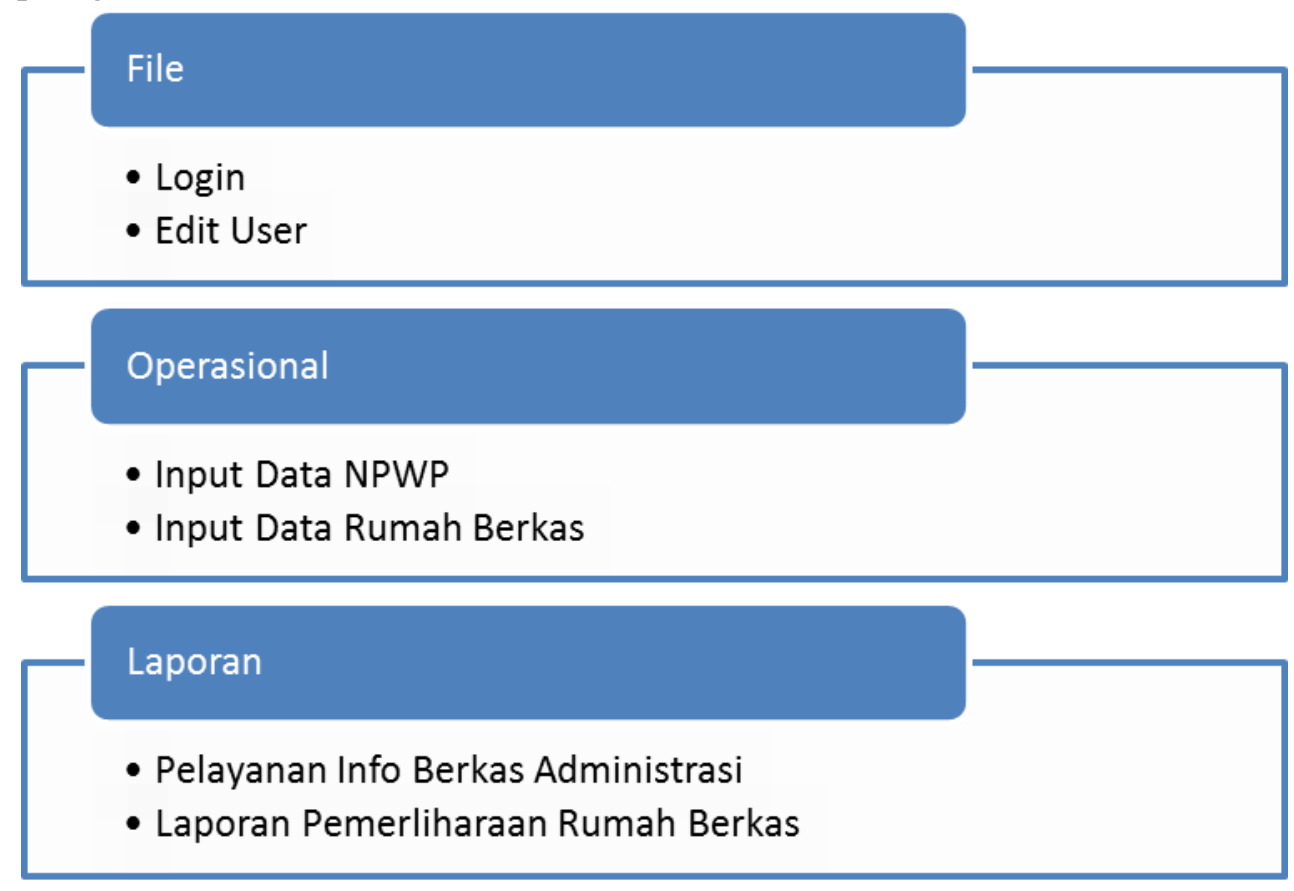

Gambar 6. Menu utama aplikasi pengelolaan arsip surat tagihan pada rumah berkas

\section{HASIL DAN PEMBAHASAN}

Aplikasi yang dibangun cukup sederhana namun memuat semua kebutuhan dari pengguna yaitu Bagian Pelaksana, untuk dapat membantu proses pemeliharaan dan pengelolaan rumah berkas wajib pajak. Fasilitas yang dimiliki aplikasi ini adalah (1) dapat menyimpan data wajib pajak dan rincian berkas arsip surat apa saja yang dimiliki oleh wajib pajak berserta posisipadalemari arsip; (2) dapat mengetahui jika ada surat tagihan tahapan sebelumnya yang belum tersimpan jika akan menyimpan data surat tagihan baru; (3) dapat menyajikan informasi tagihan terakhir yang dikenakan pada wajib pajak.

Aplikasi ini mengharuskan penggunanya untuk login sebelum masuk ke menu utama. Hal ini membuat aplikasi yang dibangun lebih aman dari akses pihak-pihak yang tidak berwenang. Pengguna utama yang dapat mengakses aplikasi ini adalah staf Bagian Pelaksana saja. Jika pengguna dapat login dan masuk ke menu utama, maka selanjutnya proses pengelolaan rumah berkas dapat dilaksanakan.

Untuk mempermudah untuk mengelola rumah berkas, aplikasi ini memuat form-form input yang digunakan sebagai perantara user dengan database. Untuk pengelolaan data wajib pajak disediakan form input seperti gambar 6(a), dengan fasilitas tambah data baru, edit dan hapus. 
Sedangkan untuk mengelola data rumah berkas yang dimiliki setiap wajib pajak dibuatkan form seperti gambar 6 (b). Dengan adanya form ini, user dapat mencari tahu letak rumah berkas setiap wajib pajak.

Detail mengenai arsip-arsip surat tagihan apa saja yang dimiliki wajib pajak dan ada pada rumah berkas, dikelola pada form dengan layout seperti gambar 6(c). Dengan adanya form ini user dapat mengontrol arsip surat apa saja yang ada fisiknya dan yang tidak ada fisiknya.

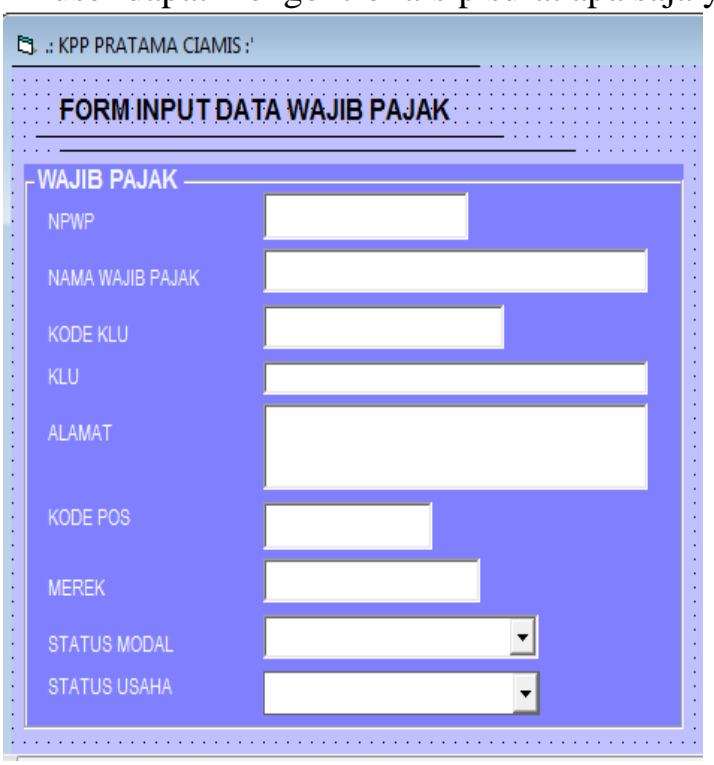

(a)

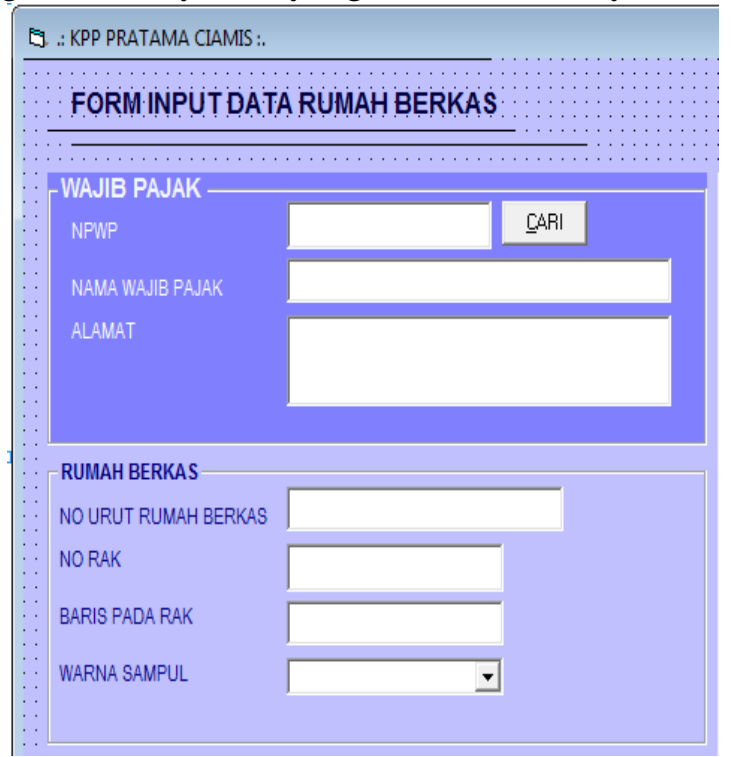

(b)

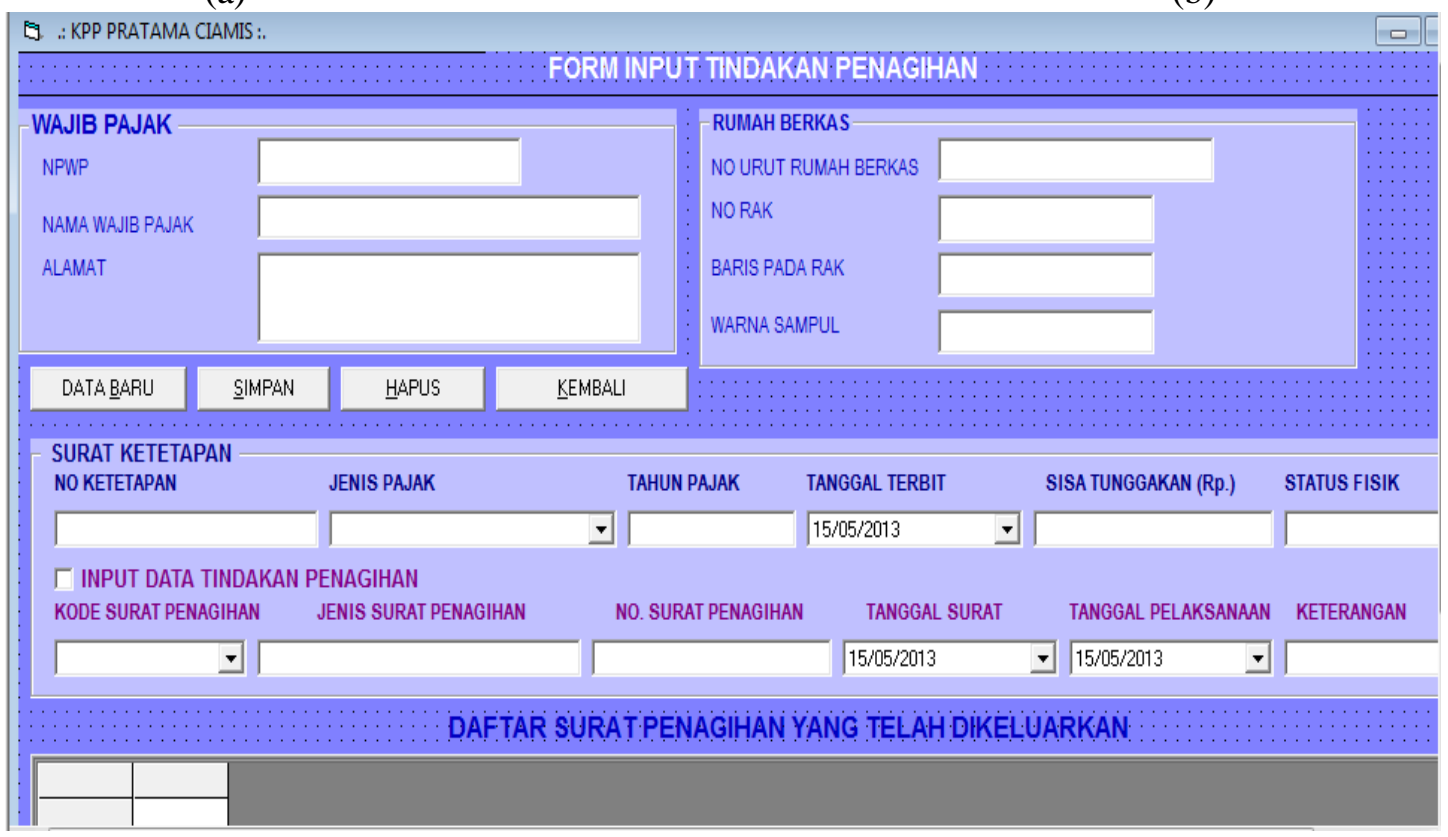

(c)

Gambar 6. Layout program pengelolaan rumah berkas surat tagihan pajak

Pada saat ada Wajib Pajak baru maka pengguna dapat menggunakan form pada gambar 6(a) untuk menginputkan datanya kemudian disimpan pada database. Selanjutnya wajib pajak tersebut memiliki satu rumah berkas yang datanya diinputkan melalui form sesuai gambar 6(b). Untuk menginput data pada form ini, pertama lakukan pencarian data wajib pajak lalu inputkan data no urut rumah berkas dan penyimpanan rumah berkas tersebut pada lemari arsip. Data ini sangat penting untuk memudahkan pencarian fisik rumah berkas selanjutnya. 
Jika wajib pajak memiliki ketetapan utang pajak, maka data surat ketetapan utang tersebut dibuatkan surat dan arsip suratnya disimpan pada rumah berkas. Sebelumnya data arsip tersebut diinputkan terlebih dahulu pada form sesuai dengan gambar 6(c). Untuk membantu kontrol fisik berkas arsip surat tersebut maka harus diinputkan keberadaan fisiknya, apakah ada atau tidak ada. Jika berkas fisik tersebut tidak ada, maka harus dilaporkan ke Kantor Pusat untuk diterbitkan kembali arsipnya.

Setelah adanya surat ketetapan utang pajak, maka jika wajib pajak tidak membayar utang tersebut dikeluarkan surat tagihan dan surat penindakan lainnya. Surat-surat tersebut arsipnya harus disimpan pada rumah berkas, sehingga datanya dapat diinputkan pada database menggunakan form sesuai gambar 6(c) diatas. Seperti halnya arsip surat ketetapan utang, suratsurat tagihan utang pajak pun harus dicek keberadaan fisik arsipnya. Jika berkas fisik tersebut tidak ada, maka harus dilaporkan ke Kantor Pusat untuk diterbitkan kembali arsipnya.

Untuk keperluan pencarian data surat-surat tagihan utang pajak, form pada gambar 6 (c) ini dilengkapi list view yang menampilkan seluruh surat tagihan utang pajak yang ditujukan pada wajib pajak. Daftaran surat tersebut juga dilengkapi informasi keberadaan fisik arsip suratnya. Secara berkala, Bagian Pelaksana harus melaporkan keberadaan fisik dari arsip surat tagihan pajak kepada pimpinan dan kantor pusat. Oleh karena itu, aplikasi ini dilengkapi fasilitas cetak laporan seperti pada gambar 7 .

\begin{tabular}{|c|c|c|c|c|c|c|c|}
\hline \multicolumn{8}{|c|}{ DAFTAR KETETAPAN PAJAK DENGAN STATUS FISIK ADA PADA RUMAH BERKAS } \\
\hline NO & NPWP & NAMA WAJIB PAJAK & $\begin{array}{l}\text { NOMOR KETETAPAN } \\
\text { PAJAK }\end{array}$ & $\begin{array}{l}\text { TANGGAL } \\
\text { TERBIT }\end{array}$ & $\begin{array}{l}\text { SISA TUNGGAKAN } \\
\text { PAJAK }\end{array}$ & NOMOR RAK & BARIS PADA RAK \\
\hline & & & & & & & \\
\hline & & & & & & & \\
\hline & & & & & & & \\
\hline \multicolumn{8}{|c|}{ DAFTAR KETETAPAN PAJAK DENGAN STATUS FISIK TIDAK ADA PADA RUMAH BERKAS } \\
\hline NO & NPWP & NAMA WAJIB PAJAK & $\begin{array}{l}\text { NOMOR KETETAPAN } \\
\text { PAJAK }\end{array}$ & $\begin{array}{l}\text { TANGGAL } \\
\text { TERBIT }\end{array}$ & $\begin{array}{l}\text { SISA TUNGGAKAN } \\
\text { PAJAK }\end{array}$ & NOMOR RAK & BARIS PADA RAK \\
\hline & & & & & & & \\
\hline & & & & & & & \\
\hline & & & & & & & \\
\hline & & & & & & & \\
\hline
\end{tabular}

Gambar 7. Layout laporan daftar ketetapan pajak berdasarkan status fisiknya

Laporan mengenai arsip surat ketetapan utang pajak dan surat tagihan utang pajak tersebut dimuat pada dokumen daftar ketetapan pajak berdasarkan status fisiknya. Laporan ini hanya tinggak dicetak saja melalui aplikasi pengelola rumah berkas ini. Laporan tersebut terdiri dari 2 jenis yaitu daftar ketetapan dengan status fisik ada dan status fisik tidak ada. Kedua daftaran tersebut diserahkan ke Pimpinan lalu untuk daftaran ketetapan dengan status tidak ada akan dikirim ke Kantor Pusat untuk dimintakan penerbitan kembali arsip suratnya.

Dengan fasilitas-fasilitas yang ada pada aplikasi pengelola rumah berkas ini dianggap sudah dapat membantu Bagian Pelaksana dalam mengelola dan mengontrol arsip surat tagihan utang pajak setiap wajib pajak. Sehingga proses penagihan dan penyelesaian masalah utang pajak setiap wajib pajak dapat dipantau dengan baik dan sesuai aturan yang berlaku. 


\section{KESIMPULAN}

Beberapa kesimpulan dari aplikasi pengelolaan rumah berkas ini, antara lain sebagai berikut:

a) Aplikasi ini mampu menyajikan menyimpan data berkas admisnitrasi wajib pajak berdasarkan nomor urut rumah berkas dan NPWP serta menyajikan informasi penyimpanan arsip dengan cepat dan mudah.

b) Aplikasi ini dapat menampilkan informasi jenis-jenis berkas administrasi terkait utang pajak yang dimiliki tiap NPWP dan mencetak laporan pemeliharaannya secara berkala.

c) Dengan adanya laporan-laporan yang dapat disesuaikan dengan kebutuhan, meningkatan pengawasan terhadap fisik arsip surat ketetapan utang dan surat tagihan utang pajak yang ada pada setiap rumah berkas wajib pajak.

\section{SARAN}

Untuk bahan pengembangan aplikasi sistem informasi pemeliharaan rumah berkas administrasi wajib pajak ini dapat disarankan pengembangan pada data base dan aplikasi berbasis jaringan (client server) sehingga informasi keberadaan berkas admisnistrasi bisa diakses oleh siapa saja tanpa harus melalui bagian pelaksana.

\section{UCAPAN TERIMA KASIH}

Penulis mengucapkan terima kasih kepada Pimpinan STMIK Tasikmalaya yang telah memberi dukungan financial terhadap penelitian ini.

\section{DAFTAR PUSTAKA}

[1] Judisseno, R. K., 2005, Pajak dan Strategi Bisnis Suatu Tinjauan tentang Kepastian Hukum dan Penerapan Akuntansi di Indonesia, Revisi. Jakarta: Gramedia Pustaka Utama.

[2] Puspitasari, C. D., 2010, Penagihan Pajak dengan Surat Paksa di KPP Pratama Semarang candisari, Unika Soegijapranata.

[3] Anzhori, G. and Rahmah, E., 2013, Sistem Penataan Arsip Dinamis pada Subbagian Penentuan Bidang Pidana Umum Pengadilan Negeri Payakumbuh, Ilmu Inf. Perpust. dan Kearsipan, vol. 1, no. 2, pp. 32-38.

[4] Kristanto, I. H., 1994, Konsep \& Perancangan Database. Penerbit Andi.

[5] Kadir, A., 2008, Pengenalan Sistem Informasi. Yogyakarta: Andi.

[6] Kristanto, A., 2008, Perancangan Sistem Informasi dan apilkasinya. Yogyakarta: Gava Media.

[7] Anggraeni, D. and Iriani, S., 2013, Sistem Informasi Pengarsipan Surat Masuk Dan Surat Keluar Pada Kantor Kecamatan Pringkuku, Indones. J. Secur. Syst., no. 24, pp. 1-4.

[8] Putri, W. A., 2014, Program Aplikasi Dokumentasi Surat Masuk dan Surat Keluar Pada Prodi Sistem Informasi Universitas Widyatama Bandung, Universitas Widyatama.

[9] Winiarti, S., 2012, Pemanfaatan Teorema Bayes dalam Penentuan Penyakit THT, J. Inform., vol. 2, no. 2, pp. 189-199.

[10] Al-Fatta, H., 2007, Analisis dan Perancangan Sistem Informasi. Andi.

[11] Jogiyanto, H., 2005, Analisis dan Desain Sistem Informasi. Yogyakarta: Andi. 